\title{
Interaction of microcrystalline chitosan with graphene oxide (GO) and magnesium ions in aqueous solution
}

Marta E. Lichawska*, Aleksander Kufelnicki and Magdalena Woźniczka

\begin{abstract}
Background: Thanks to its specific chemical and physical properties, graphene has aroused growing interest in many fields of Science and Technology. The present study focuses on the properties of microcrystalline chitosan (MCCh): a compound known to increase the biocompatibility of various matrices, including those made of graphene layers, enabling the controlled release of molecules of therapeutic compounds. The study exploits the potential of MCCh to complex with metal ions, in this case $\mathrm{Mg}^{2+}$, and attempts to describe such interactions when the system is enriched with graphene oxide $(\mathrm{GO})$. These findings would open completely new areas of knowledge about $\mathrm{GO}$ as a drug carrier.

Results: Potentiometric analysis found that in the GO-Mg system, complexes of ML'type were formed, where $M=M g^{2+} ; L^{\prime}=G O\left(\log \beta_{11^{\prime} 0}=9.5(3)\right)$ and $M^{\prime} L_{2}^{\prime}\left(\log \beta_{12^{\prime} 0}=13.2(4)\right)$, whereas in the GO-Mg ${ }^{2+}-M C C h$ system, a mixedtype complex MLL' was also formed, in which L = MCCh: this complex demonstrated the overall stability constants $\log \beta_{111^{\prime}}=11.2$ (3) for degree of deacetylation DD 74.4\% and $\log \beta_{111^{\prime}}=12.4$ (4) for DD 97.7\%. FT-IR analysis showed interactions in the GO-Mg ${ }^{2+}-\mathrm{MCCh}(\mathrm{DD}=97.7 \%)$ system. In addition, the amide $\|-\mathrm{NH}$ band was displaced from $1623 \mathrm{~cm}^{-1}$ to two bands at $1633 \mathrm{~cm}^{-1}$ and $1648 \mathrm{~cm}^{-1}$, resulting from the interaction of the metal ion, and the absorption band of the corresponding NH in the chitosan acetyl group was shifted from 1304 to $1351 \mathrm{~cm}^{-1}$. When chitosan with a deacetylation degree lower than $74.4 \%$ was applied, the amide bands I and II differed only in their intensity. A greater impact on absorption was observed for the acetyl NH group of chitosan, for which the corresponding band shifted from 1319 to $1361 \mathrm{~cm}^{-1}$.

Conclusions: The results confirm the ability of $\mathrm{GO}-\mathrm{Mg}^{2+}-\mathrm{MCCh}$ to create complex arrangements. It can form a basic complex of one metal ion and one ligand molecule $(G O)$ in the case of $M L^{\prime}$ (where $L^{\prime}=G O$ ), or two molecules of $\mathrm{GO}$ with a metal ion $\mathrm{M}\left(\mathrm{Mg}^{2+}\right)$ in the case of $\mathrm{ML}_{2}^{\prime}$. A mixed complex of $\mathrm{MLL}^{\prime}$ type is also formed, with two ligands: $\mathrm{L}=$ MCCh with deacetylation degrees $\mathrm{DD}=74.4 \%$ and $97.7 \%$ and graphene oxide $\mathrm{L}^{\prime}=\mathrm{GO}$. In the latter case, FT-IR spectroscopy was used to confirm the mode of interaction. The $\mathrm{GO}-\mathrm{Mg}^{2+}-\mathrm{MCCh}$ system may be used as carrier in modern magnesium containing medicines or as auxiliary substances in pharmacy.
\end{abstract}

Keywords: Biomaterials, graphene oxide (GO), Microcrystalline chitosan, Metal-polymer complexes, Equilibria in aqueous solution

\footnotetext{
*Correspondence: marta.lichawska@umed.lodz.pl

Department of Physical and Biocoordination Chemistry, Faculty

of Pharmacy, Medical University of Łódź, 90-151 Łódź, Poland
}

(c) The Author(s) 2019. This article is distributed under the terms of the Creative Commons Attribution 4.0 International License (http://creativecommons.org/licenses/by/4.0/), which permits unrestricted use, distribution, and reproduction in any medium, provided you give appropriate credit to the original author(s) and the source, provide a link to the Creative Commons license, and indicate if changes were made. The Creative Commons Public Domain Dedication waiver (http://creativecommons.org/ publicdomain/zero/1.0/) applies to the data made available in this article, unless otherwise stated. 


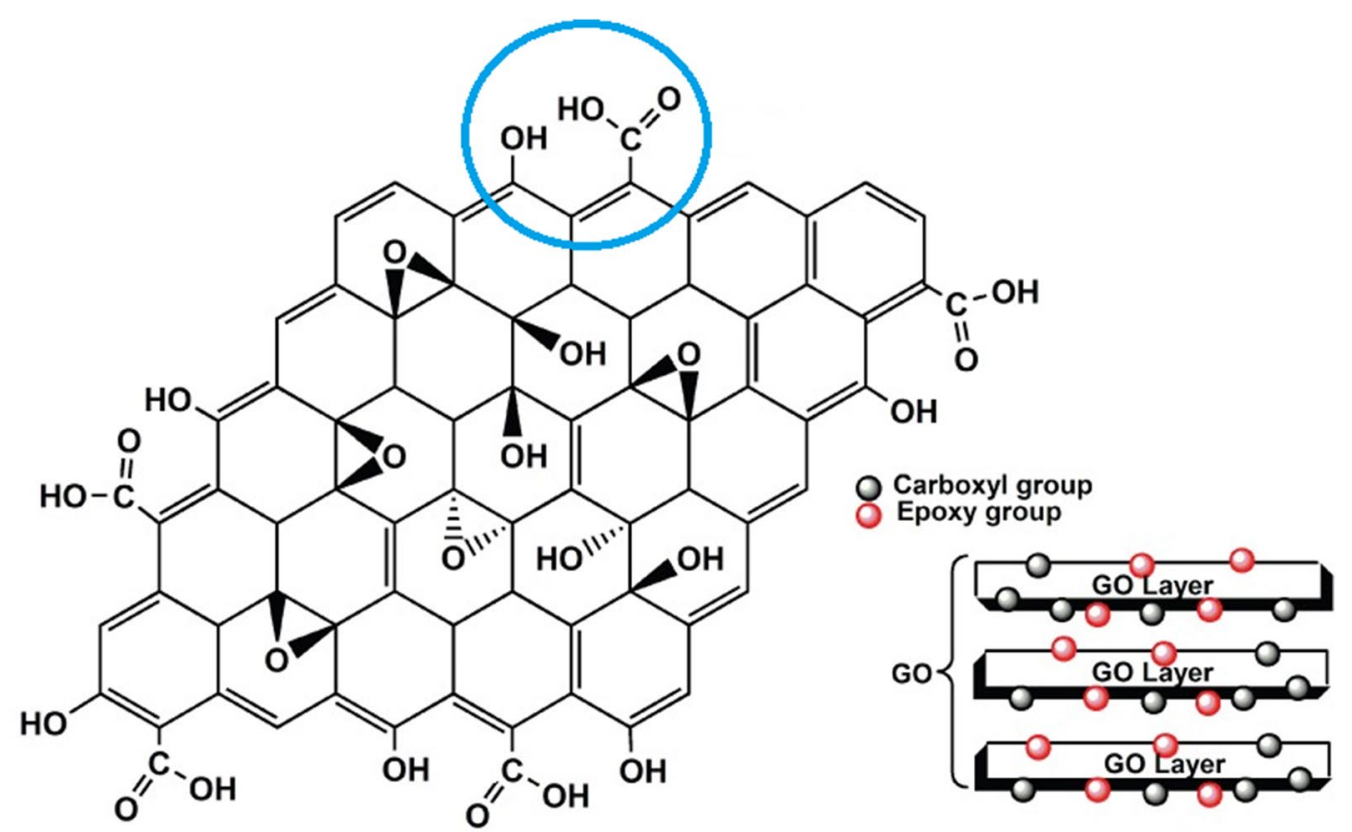

Fig. 1 The arrangement rings and functional groups in a single layer of graphene [8]

\section{Introduction}

Graphene is characterized by specific chemical and physical properties and has therefore been the subject of a great deal of research regarding its potential applications in Science and Technology. The oxidized derivative of graphene is known as graphene oxide (GO), which is obtained from graphite oxide, also originally referred as GO [1]. GO is used as a substrate in nano-electronics, composite materials, energy technology, sensors and catalysis [2], and is under evaluation for use as a nanocarrier in medications [3].

The presence of certain functional groups makes GO biocompatible, stable in aqueous solution and compatible with polymers such as chitosan. Functional oxygen groups such as hydroxyl $(\mathrm{OH})$, carbonyl $(\mathrm{C}=\mathrm{O})$ and carboxyl $(\mathrm{COOH})$ [4] can link to the $\mathrm{GO}$ molecule, allowing it to interact with various systems. Graphene oxide itself can be obtained by the oxidation of graphene using a wide variety of compounds, including nitric acid (V), sulfuric acid (VI) and potassium permanganate [5].

Although a number of studies have examined the synthesis of graphene and its oxide, relatively little is known of their chemical structures. Such analysis is complicated by the fact that they are non-stoichiometric compounds, and their structure is strictly dependent upon the conditions used during synthesis. Even so, a precise knowledge of their structure is nevertheless essential if these substances are to be used correctly in everyday applications [6]. Graphene is, however, known to be a variant of allotropic carbon, with a two-dimensional structure of monatomic thickness. The carbon atoms form a sixmembered hybridized $\mathrm{sp}^{2}$ structure resembling a honeycomb [7]. The structure of this material has a significant impact on its properties, which are also influenced by the type and location of functional groups, as shown in Fig. 1 [8].

The latest model of GO has been derived from nuclear magnetic resonance spectroscopy (NMR) [6]. The compound appears to consist of two regions: an aromatic region with non-oxidized benzene rings and an aliphatic region consisting of six-membered rings. Oxygens containing functional groups, such as epoxy and hydroxyl, are located in the basal plane, with carboxyl groups and hydroxyl groups located at the edges. This structure has been confirmed by high-resolution transmission electron microscopy (TEM) [9]. Any further analysis of the interactions of GO presented in this work are based precisely on the structure proposed by Lerf and Klinowski [6].

GO shows a very high ability to accumulate in the lungs, spleen, liver and kidneys, and the lack of biodegradation and the potential for long-term toxicity associated with the presence of oxygen functional groups are major causes for concern when using GO in biomedical applications. Despite this, extensive research has identified ways to reduce toxicity. Some studies indicate the presence of a relationship between GO particle size and hemolytic activity, with smaller particle sizes being associated with greater hemolytic activity and vice versa. Therefore, 


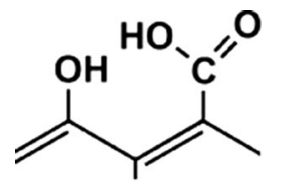

Fig. 2 The basic structure of a graphene oxide fragment responsible for coordination of the metal ion

layering of the analyzed compound by chitosan, a polysaccharide biopolymer composed of D-glucosamine (2-amino-2-deoxy-D-glucose) and $\mathrm{N}$-acetyl-D-glucosamine (2-acetamido-2-deoxy-D-glucose), should result in complete elimination of this activity. Such investigations are in progress, although their results are not yet fully clear.

Microcrystalline chitosan (MCCh) is one of the most common modifications of basic chitosan. The polymer exhibits a number of beneficial properties, such as biocompatibility, decomposition into non-toxic products, and broad antiviral, antifungal and antibacterial activity. This aim of the present study is to determine the biocompatibility of MCCh formed from various substrates, including graphene layers, which allow for controlled release of molecules for therapeutic compounds [10]. Due to their great importance to the human body, $\mathrm{Mg}^{2+}$ ions were chosen to investigate the potential of the $\mathrm{GO}+\mathrm{MCCh}$ combination to complex metal ions. Such studies could provide new knowledge of GO as a drug carrier or excipient $[11,12]$. Chitosan films treated with GO have already been investigated by Ping Zuo et al. [3] using a range of analytical techniques including X-ray analysis, electron spectroscopy, differential scanning calorimetry and gravimetric analysis; the findings indicate that these films are subject to tensile forces which increase significantly in the presence of GO. In addition, such a system shows greater thermal stability than chitosan. Moreover it remains biocompatible and biodegradable, and possesses good solubility in aqueous systems, similar to chitosan alone.

\section{Results and discussion}

\section{Complex formation $\mathrm{GO}$ with $\mathrm{Mg}^{2+}$ and GO-Mg-MCCh}

To determine the properties of graphene oxide (GO) with $\mathrm{Mg}^{2+}$ ions, it was first necessary to identify the protonation constants of the ligand. The ligand GO was conventionally called a molecule, because GO did not display any separate, repeatable mers, unlike the case of typical polymers, which possess an indefinite molecular formula. A molecular unit with an approximate molecular weight of 98.04 was identified according to the Lerf-Klinowski model (Fig. 2), taking into account the nearest vicinity of the functional groups involved in coordination of $\mathrm{Mg}^{2+}$.

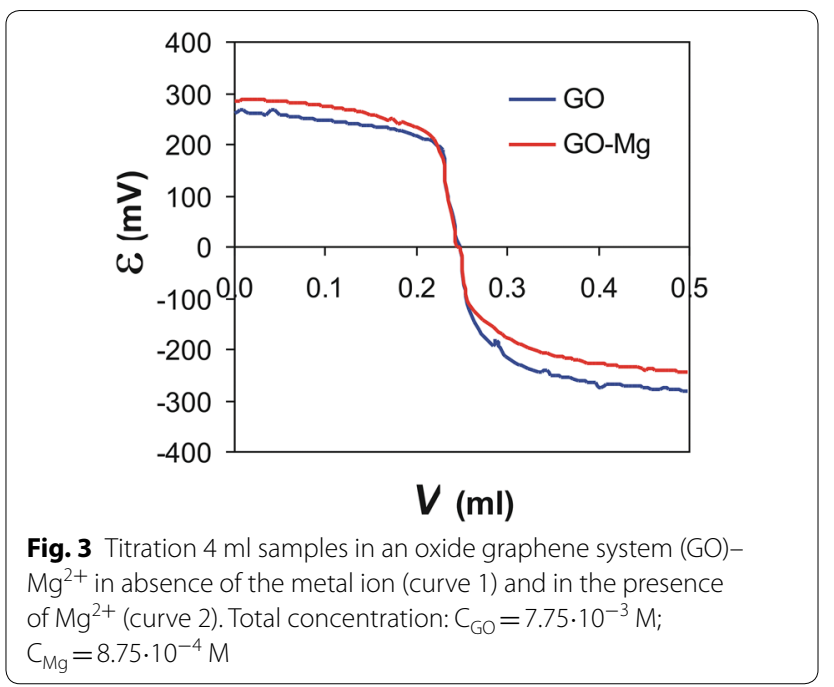

Based on the determined density of the aqueous GO suspension at a given temperature, it was then possible to calculate the mass of GO in a $4 \mathrm{ml}$ volume of the sample, and thus the number of mmol present.

The graph in Fig. 3 showing the relationship between the electromotive force of the cell and the volume of the added base solution indicates an increase of the SEM value for the curve of $\mathrm{Mg}^{2+}$ (curve 2); this increase corresponds to reduction in $\mathrm{pH}$ due to the complexing deprotonation of functional groups. The calculations allowed two protonation constants for $\mathrm{GO}$ to be determined: $\log$ $\beta_{01^{\prime} 1}=9.96$ (5) for the carboxyl group and $\log \beta_{01^{\prime} 2}=12.60$ (5) for the hydroxyl group.

A graph indicating the percentage of the protonated form (Fig. 4) against pH shows that in an acidic medium, the first proton is dissociated from the carboxyl group $(\mathrm{COOH})$, while a proton from the $-\mathrm{OH}$ group is removed together with further alkalization of the solution.

The next stage of the experiment was to determine the stability constants for the system $\mathrm{GO}-\mathrm{Mg}^{2+}$. The equilibrium model assumes that different possibilities exist for the formation of simple ML complexes, e.g. $\mathrm{ML}^{\prime} \mathrm{ML}_{2}$, $\mathrm{ML}_{3}$ : the central atom is a metal cation $\mathrm{M}-\mathrm{Mg}^{2+}$ surrounded by L'-GO ligands. The possible protonated forms $M L ' H$ and $\mathrm{ML}_{2}{ }_{2} \mathrm{H}$ are explained by the presence of a central atom with one or two ligands and the simultaneous protonation of the $\mathrm{OH}-\mathrm{GO}$ group. By matching the proposed theoretical model to the experimental curve, two simple complex types were identified, $\mathrm{ML}^{\prime}$ and $\mathrm{ML}_{2}$, with the respective formation constants $\log \beta_{11^{\prime} 0}=9.5$ (3) and $\log \beta_{12^{\prime} 0}=13.2$ (4), where ML' indicates a complex involving one metal ion and one GO ligand molecule, and $\mathrm{ML}_{2}$ indicates two GO particles in combination with a metal ion. 


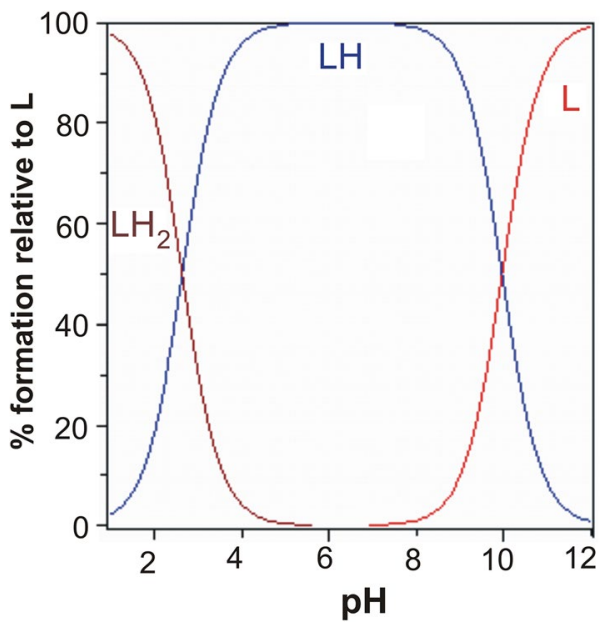

Fig. 4 Percentage of protonated $\mathrm{GO}$ species as a function of $\mathrm{pH}$. Sample of volume $4 \mathrm{ml}$ contained $0.031 \mathrm{mmol} \mathrm{GO}$ and $0.030 \mathrm{mmol}$ of $\mathrm{HNO}_{3}$

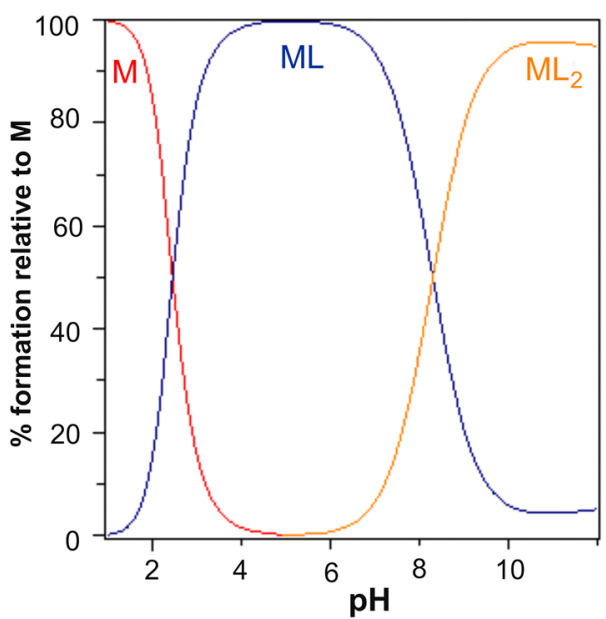

Fig. 5 The percentage of the complexes formed in the GO-Mg system

The simple complex type (ML) reaches a maximum at around $\mathrm{pH} 5$ (Fig. 5). The share of the $\mathrm{ML}_{2}$ complex increases as alkalization continues, with a maximum level reached around pH 11.
The determined stability constants for the $\mathrm{GO}-\mathrm{Mg}^{2+}$ system were used for the equilibrium model of the heteroligand system $\mathrm{MCCh}-\mathrm{Mg}^{2+}-\mathrm{GO}$. At this stage, MCCh with two degrees of deacetylation ( $\mathrm{DD}=74.4 \%$ and 97.7\%) was applied. An initial $\log \beta_{111}$ ' value of 14.0 (MLL') for the mixed complex was established (Table 1).

In the case of the mixed complexes comprising two ligands, i.e. GO and MCCh of DD $74.4 \%$ or $97.7 \%$ and a metal ion, single titration curves were characterized by a local discontinuity, leading to a greater standard deviation for each formation constant (Table 2).

The simulated species distribution diagram of the formed complexes in the $\mathrm{GO}-\mathrm{Mg}^{2+}-\mathrm{MCCh}$ system (Fig. 6) showed the presence of the following complexes : ML, ML', ML', MLL' (with a maximum level at about $\mathrm{pH}$ 8.5), $\mathrm{ML}_{2}$ ( (L-chitosan, L'-GO, M- $\mathrm{Mg}^{2+}$ ). MCCh only constituted a very small share of the ML complex, contrary to the ML' GO complex.

\section{Infrared spectra}

To confirm the potentiometric results in $\mathrm{GO}-\mathrm{Mg}^{2+}$ MCCh, further FT-IR study was performed. The analysis examined the spectra obtained for GO, MCCh, $\mathrm{GO}-\mathrm{Mg}^{2+}-\mathrm{MCCh}$ and $\mathrm{MCCh}-\mathrm{Mg}$ at various $\mathrm{pH}$ values and degrees of MCCh deacetylation. Figures 7 and 8 present the FT-IR spectrum for the GO-MCCh complex at $\mathrm{DD}=97.7 \%$.

The FT-IR spectra (Fig. 7) for GO reveal the presence of a large number of functional groups such as $\mathrm{OH}, \mathrm{COOH}$, $\mathrm{C}=\mathrm{O}, \mathrm{C}-\mathrm{OH}$ and $\mathrm{C}-\mathrm{O}-\mathrm{C}$ [17]. The FT-IR spectrum for MCCh shown in Fig. 8 reveals a wide band in the range $2500-3500 \mathrm{~cm}^{-1}$, overlapping the stretching vibrations of the $\mathrm{OH}$ and $\mathrm{N}-\mathrm{H}$ groups. The $\mathrm{C}=\mathrm{O}$ band in amide group $\mathrm{I}$ is present at $1624 \mathrm{~cm}^{-1}$, while the $\mathrm{NH}$ group of amide II can be observed at $1529 \mathrm{~cm}^{-1}$. A band corresponding to a $\mathrm{CH}$ group can be seen at $2935 \mathrm{~cm}^{-1}$. Another band at $1313 \mathrm{~cm}^{-1}$ corresponds to the $\mathrm{NH}$ group in $\mathrm{NH}-\mathrm{CO}$. The high intensity of the bands within the range 800 $1200 \mathrm{~cm}^{-1}$ reveals the presence of a repeated pyranose ring structure present in the chitosan [3].

Table 1 The constants used in the calculations for heteroligand complexes

\begin{tabular}{ll}
\hline $\log \beta_{011}=6.50(\mathrm{LH})$ & Protonation constant of MCCh $[13,14]$ \\
$\log \beta_{01}{ }_{1}=9.96\left(\mathrm{~L}^{\prime} \mathrm{H}\right)$ & The first protonation constant of $\mathrm{GO}$ for the $\mathrm{OH}^{-}$group, determined under the conditions of the current experiment \\
$\log \beta_{01}{ }_{2}=12.60\left(\mathrm{~L}^{\prime} \mathrm{H}_{2}\right)$ & The second protonation constant of $\mathrm{GO}$ for the $\mathrm{COO}^{-}$group, determined under the conditions of the current experiment \\
$\log \beta_{00-1}=-13.77\left(\mathrm{H}^{-1}\right)$ & $\mathrm{PK}_{\mathrm{w}}$ \\
$\log \beta_{10-1}=-11.70\left(\mathrm{MH}^{-1}\right)$ & Hydrolysis constant of $\mathrm{Mg}^{2+}[15]$ \\
$\log \beta_{110}=3.29(6)(\mathrm{ML})$ & The value obtained from previous tests for the system MCCh-Mg ${ }^{2+}[16]$ \\
$\log \beta_{111}{ }^{\prime}=14.0(\mathrm{MLL})$ & In this case, it was assumed that the central atom $\mathrm{Mg}^{2+}$ is surrounded by the ligand molecule L-MCCh and ligand $\mathrm{L}^{\prime}-\mathrm{GO}$ \\
\hline
\end{tabular}


Table 2 Summary of the formation constants of simple and mixed complexes

$\begin{array}{lll}\mathrm{GO}-\mathrm{Mg}^{2+} & \mathrm{GO}-\mathrm{Mg}^{2+}-\mathrm{MCCh} & \mathrm{GO}-\mathrm{Mg}^{2+}- \\ & \mathrm{SD} \mathrm{74.4 \%} & \mathrm{MCCh} \text { SD } \\ & 97.7 \%\end{array}$

\begin{tabular}{|c|c|c|c|}
\hline $\log \beta_{11}^{\prime}$ & $9.5(3)$ & & \\
\hline $\log \beta_{12}^{\prime} 0$ & $13.2(4)$ & & \\
\hline $\log \beta_{111}{ }^{\prime}$ & & $11.2(3)$ & $\beta_{111^{\prime}}=12.4$ (4) \\
\hline
\end{tabular}

The precise description of the individual spectra allowed for a better understanding of the interactions taking place in GO-Mg-MCCh [18]. As the presence of random $\mathrm{pH}$ values leads to poorly-differentiated spectra, a further analysis of the resulting curves were used for extreme $\mathrm{pH}$ values (Fig. 9). FT-IR analysis of GO$\mathrm{Mg}-\mathrm{MCCh}$, at $\mathrm{DD}=97.7 \%$ revealed displacement of the amide $1623 \mathrm{~cm}^{-1} \mathrm{II}-\mathrm{NH}$ band towards longer wave numbers, and its cleavage into two bands at $1633 \mathrm{~cm}^{-1}$ and $1648 \mathrm{~cm}^{-1}$, a change resulting from the interaction with the metal ion [19], and the band-shift of the chitosan acetyl NH group from $1304 \mathrm{~cm}^{-1}$ up to $1351 \mathrm{~cm}^{-1}$. When chitosan with a lower degree of deacetylation $(\mathrm{DD}=74.4 \%)$ was applied, changes in the amide bands (amide I and II) were found to differ only in their intensity (Fig. 10). More pronounced changes were revealed for the absorption band of the $\mathrm{NH}$ of the acetyl group, of chitosan whose value moved from 1319 to $1361 \mathrm{~cm}^{-1}$. The above analysis indicates the existence of coordination
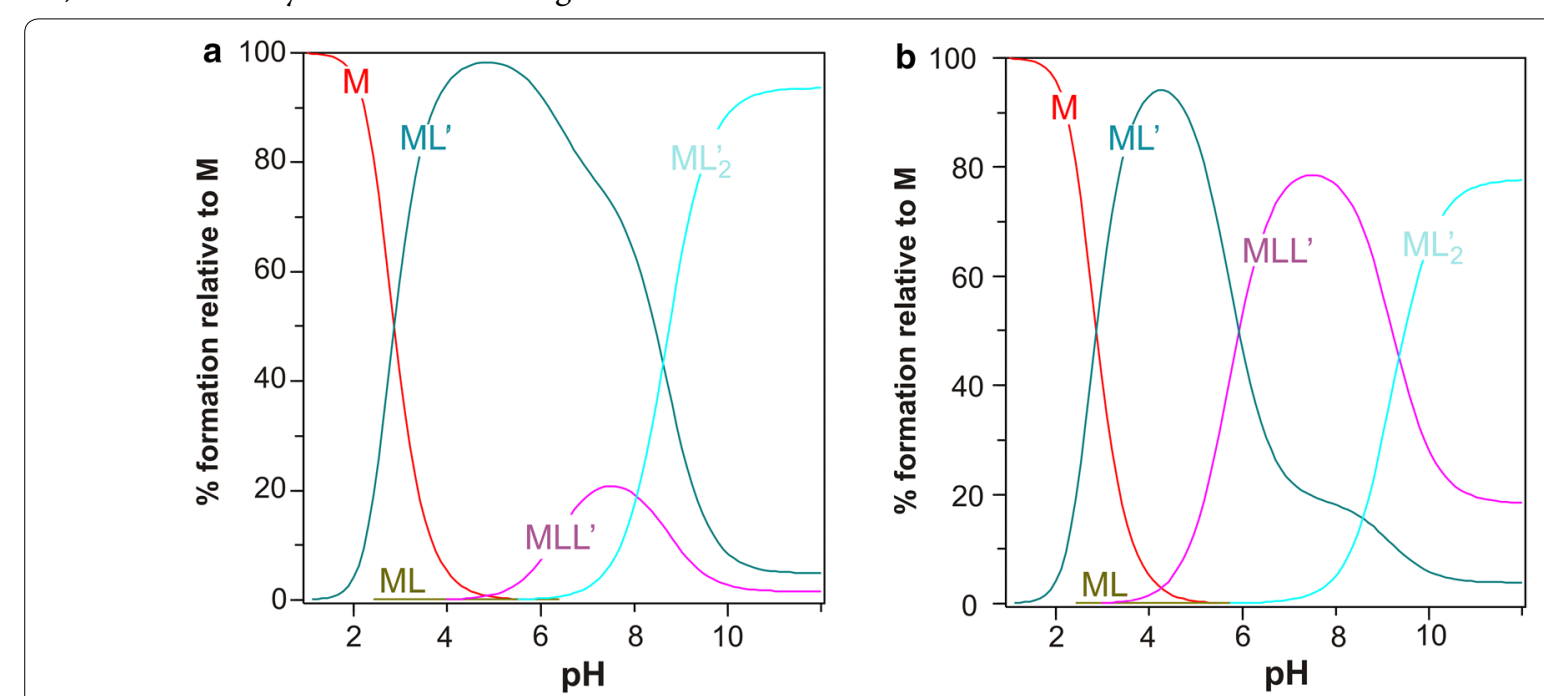

Fig. 6 Simulated percentage of the formed complexes as a function of $\mathrm{pH}$ for the $\mathrm{GO}-\mathrm{Mg}^{2+}-\mathrm{MCCh}$ system. The MCCh gel of deacetylation degree $\mathrm{DD}=74.4 \%(\mathbf{a})$ and $97.7 \%(\mathbf{b})$, respectively. Program HySS

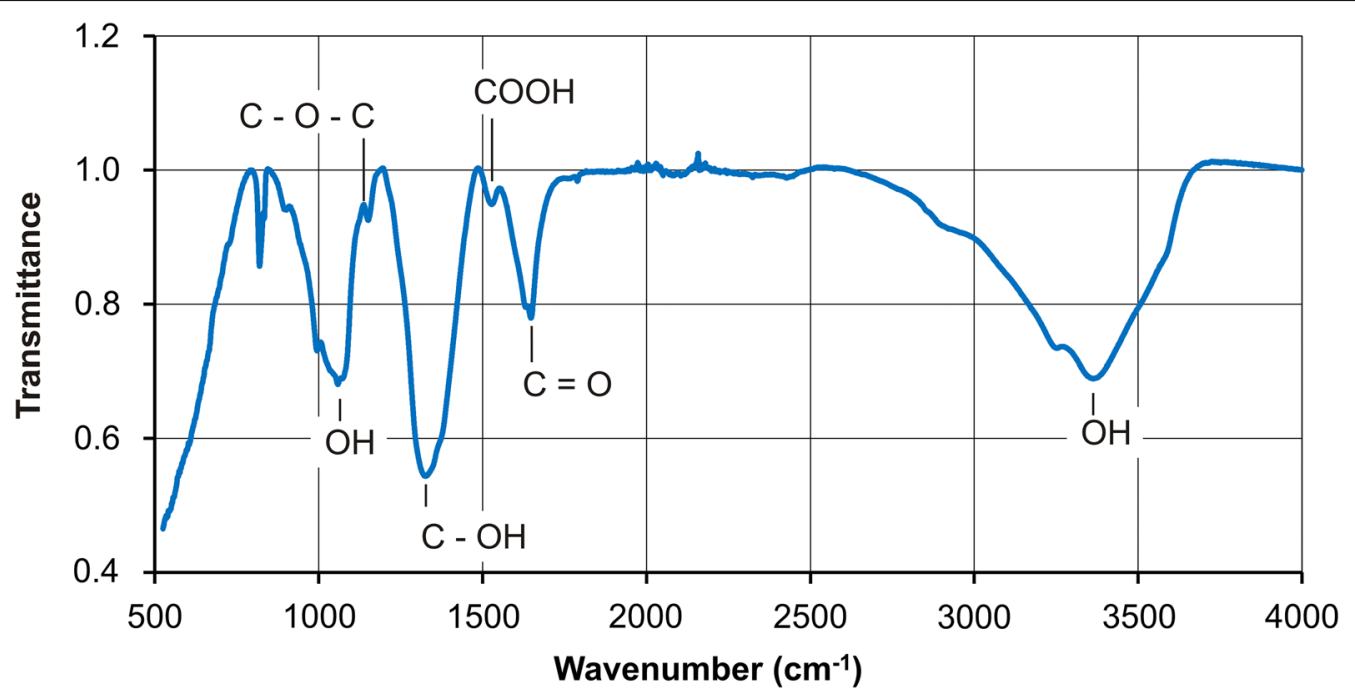

Fig. 7 FT-IR spectrum of graphene oxide (GO) 


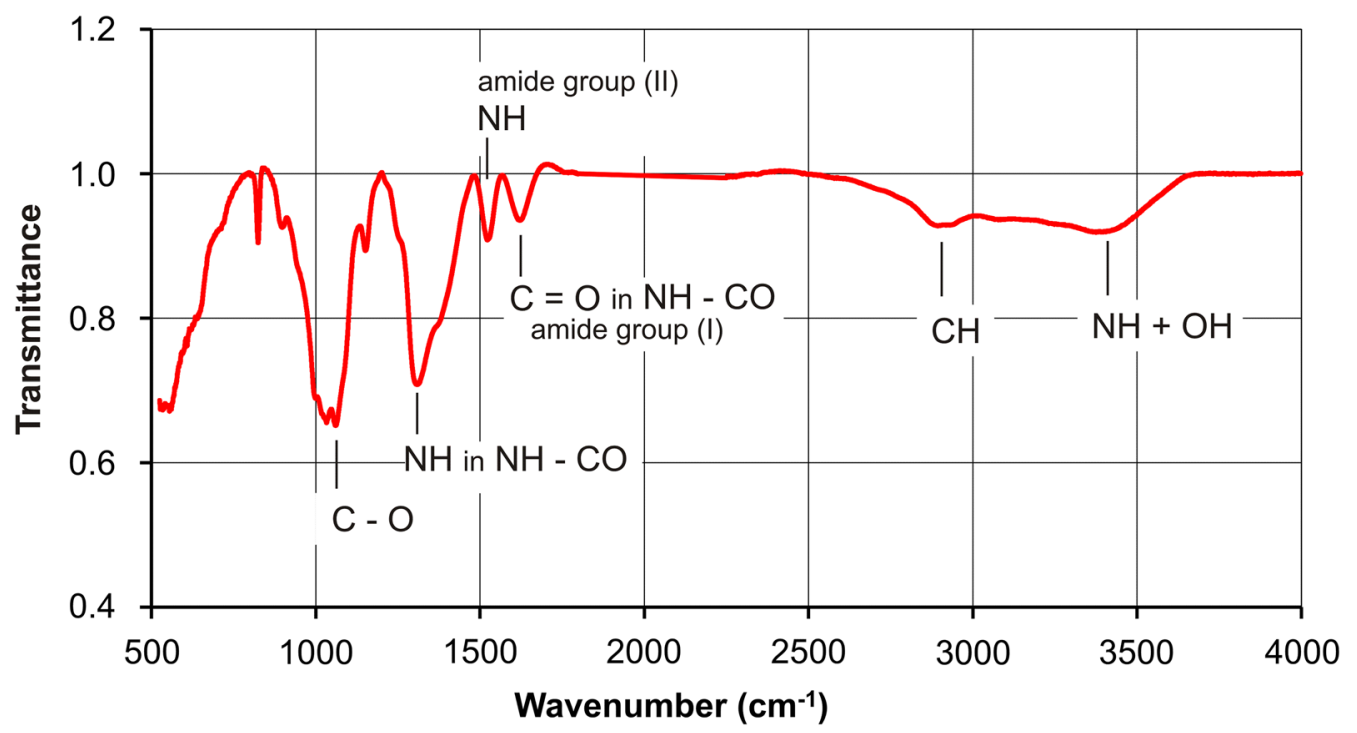

Fig. 8 FT-IR spectrum for microcrystalline chitosan (MCCh) of deacetylation degree DD 97.7\%

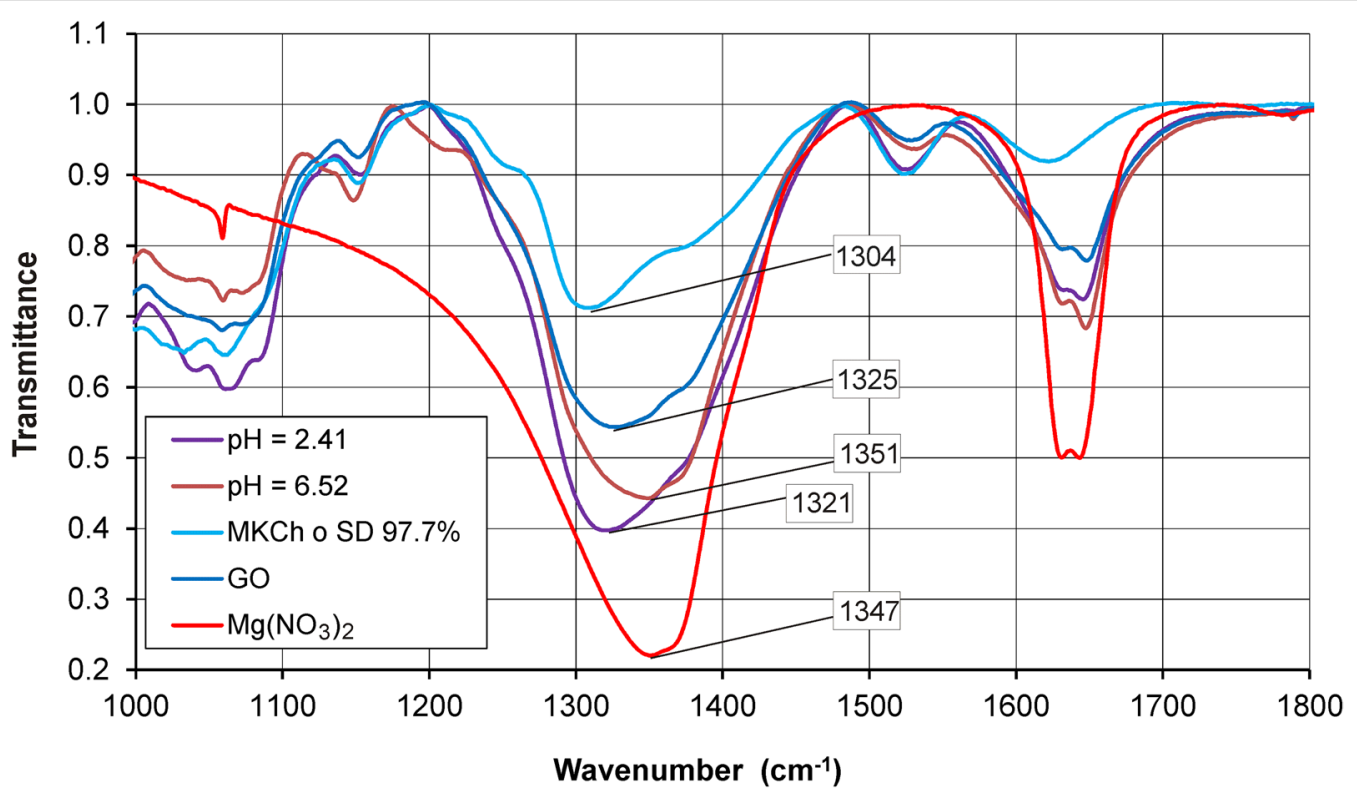

Fig. 9 FT-IR spectrum for the GO-Mg-MCCh system of DD 97.7\% at extreme $\mathrm{pH}$ values

interactions between GO, MCCh and the metal ion, in this case, the magnesium ion.

Figure 11 proposes a model of coordination for GO$\mathrm{Mg}-\mathrm{MCCh}$. The FT-IR analysis suggests that GO first binds to magnesium ions by the $\mathrm{OH}$ group, and then to the $\mathrm{NH}$ acetyl group of chitosan. It is also possible to combine $\mathrm{GO}$ and magnesium ions with $\mathrm{COOH}$, and then with the $\mathrm{NH}$ of chitosan. It is known that in compounds containing a carboxyl group $(\mathrm{COOH})$, comprising a carbonyl group $\mathrm{C}=\mathrm{O}$ and the hydroxyl $\mathrm{OH}$, the liquid particles are strongly associated due to the presence of intermolecular hydrogen bonds. Such bonds are very strong in both the liquid and solid states. In the formation of complex compounds, the carboxylate anion OCO-coordinates with the central ion in a different way. In the case of the analyzed system, it has a monodentate character [20]. 


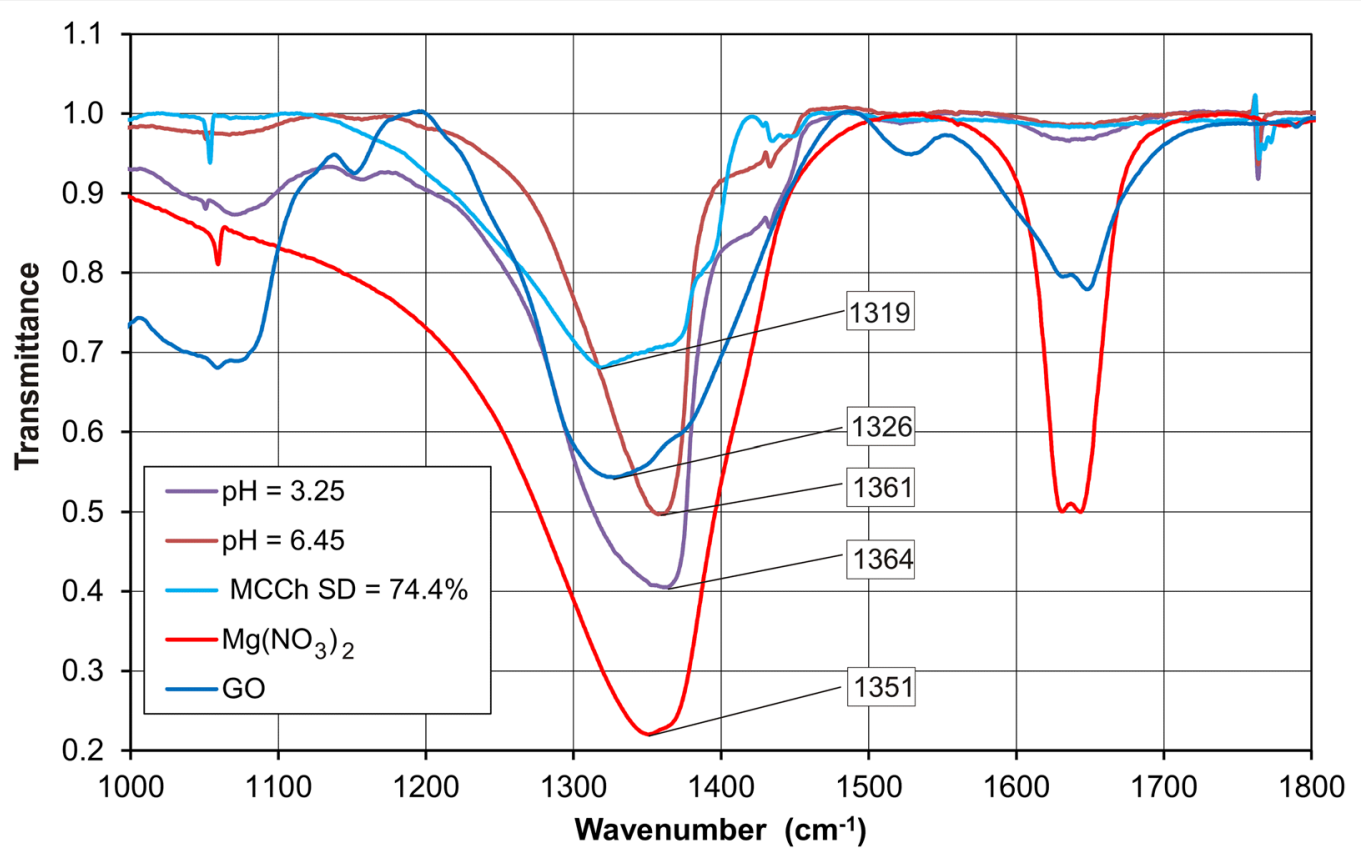

Fig. 10 FT-IR spectrum for the GO-Mg-MCCh system of DD 74.4\% at extreme $\mathrm{pH}$ values

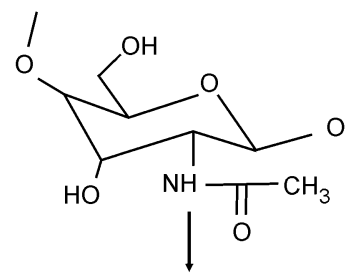

$\mathrm{Mg}$

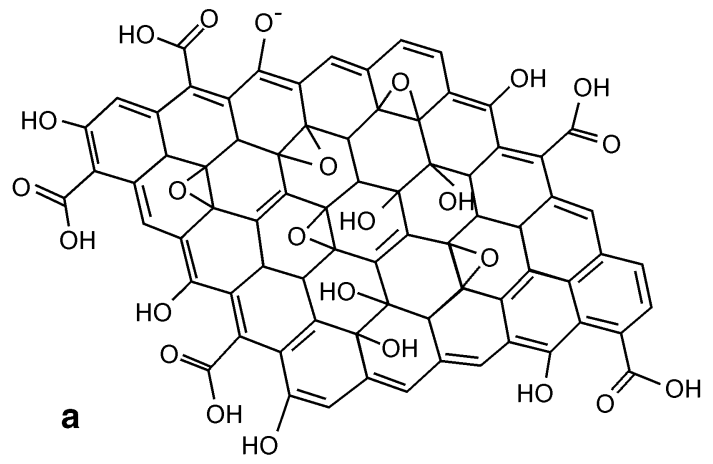

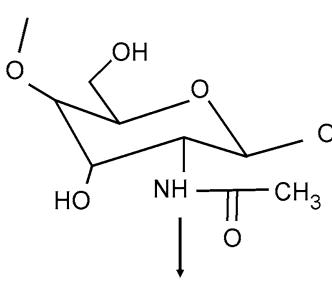<smiles>COC1OC(CO)C(C)C(O)C1N</smiles>

$\mathrm{Mg}$

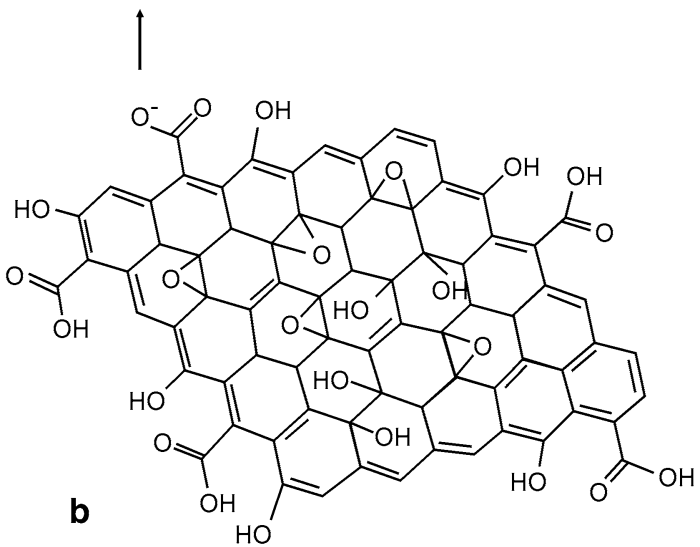

Fig. 11 Proposed coordination modes in the GO-Mg-MCCh system of DD $74.4 \%$ and $97.7 \%$, respectively. a Coordination via the $\mathrm{OH}$ group of graphene oxide, $\mathbf{b}$ via the $\mathrm{COOH}$ group of graphene oxide 


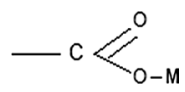

\section{Conclusions}

Our findings confirm that donor-acceptor complexes can be formed for the systems $\mathrm{GO}-\mathrm{Mg}^{2+}$ and $\mathrm{GO}-\mathrm{Mg}^{2+}$ MCCh. Further analysis of our results indicates that type $\mathrm{ML}$ ' and $\mathrm{ML}_{2}$ complexes are created in the GO-Mg ${ }^{2+}$ system, and these are accompanied by MLL' mixed complexes in the heteroligand system $\mathrm{GO}-\mathrm{Mg}^{2+}-\mathrm{MCCh}$. Our potentiometric $\mathrm{pH}$ studies confirm that the metal ion is coordinated by the oxygen of the carboxyl group and the oxygen of the hydroxyl group of GO; they also indicate that a mixed complex is formed by those groups, together with a nitrogen atom of chitosan, indicated by FT-IR spectroscopy to be an acetyl nitrogen. This greater understanding of the properties of $\mathrm{GO}-\mathrm{Mg}^{2+}-\mathrm{MCCh}$ may improve knowledge of the application of a new generation of biomaterials, such as graphene oxide and microcrystalline chitosan, as carriers of active substances of biological importance.

\section{Methods}

\section{Materials}

$\mathrm{MCCh}$-microcrystalline chitosan (weight-average molecular weight $=326.0$ and $380.0 \mathrm{kDa}$, Institute of Biopolymers and Chemical Fibers, Łódź, Poland) was used in the form of hydrogel of definite polymers contents (2.98 and $2.48 \mathrm{wt} \%$ ) at two different degrees of deacetylation: $74.4,97.7 \%$. The DD degree, necessary to estimate the amount of $-\mathrm{NH}_{2}$ groups in the samples was determined by first derivative UV-spectrophotometry (1DUVS) according to Khor et al. [21]. Briefly, $0.01 \mathrm{~mol} \mathrm{~L}^{-1} \mathrm{Mg}(\mathrm{II})$ stock solution was made up from $\mathrm{Mg}\left(\mathrm{NO}_{3}\right)_{2} \times 6 \mathrm{H}_{2} \mathrm{O}, 0.2 \mathrm{~mol} \mathrm{~L}^{-1} \mathrm{KNO}_{3}$ (POCh Gliwice), $0.1 \mathrm{~mol} \mathrm{~L}^{-1}$ from $\mathrm{HNO}_{3} 65 \%$ (Lach-Ner, Czech Republic). Carbonate-free $0.1000 \pm 0.0003 \mathrm{M} \mathrm{NaOH}$ solution (Mallinckrodt Baker B.V.) was used as titrant. Two buffers: phthalate $\left(0.05 \mathrm{~mol} \mathrm{~L}^{-1}\right.$ potassium hydrophthalate $+0.05 \mathrm{~mol} \mathrm{~L}^{-1} \mathrm{KNO}_{3}, \mathrm{pH}=3.926$ at $25^{\circ} \mathrm{C}$ ) and borax (0.01 mol L $\mathrm{L}^{-1} \mathrm{Na}_{2} \mathrm{~B}_{4} \mathrm{O}_{7} 10 \mathrm{H}_{2} \mathrm{O}+0.07 \mathrm{~mol} \mathrm{~L}{ }^{-1} \mathrm{KNO}_{3}$, $\mathrm{pH}=9.10)$ were prepared at constant ionic strength 0.1 according to [22]. GO-graphene oxide, kindly supplied by Institute of Electronic Materials Technology, Warsaw, Poland, was used in the form of black aqueous suspensions (Fig. 12), molar mass of one mer $M=98.04 \mathrm{~g} / \mathrm{mol}$.

\section{Potentiometric titrations}

A Molspin automatic titration kit (Newcastle upon Tyne, England) equipped with an OSH-10-10 combined

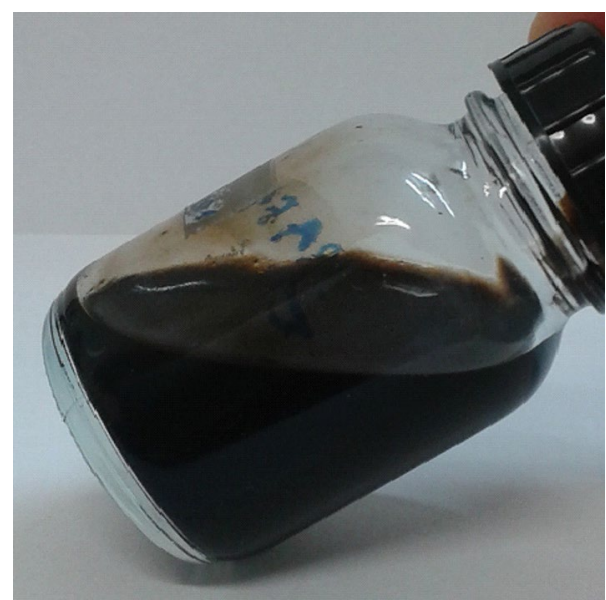

Fig. 12 An aqueous suspension of graphene oxide GO

electrode (METRON, Poland), and autoburette was used for EMF measurements. The total volume (alkali $0.1 \mathrm{~mol} \mathrm{~L}^{-1} \mathrm{NaOH}$ carbonate-free, Malinckrodt Baker B. V.) in the Hamilton microsyringe of the automatic burette was $500 \mu \mathrm{L}$. The titration course was controlled by MOLSPIN software. For the potentiometric study of the $\mathrm{GO}-\mathrm{Mg}^{2+}$ system, and of GO- $\mathrm{Mg}^{2+}-\mathrm{MCCh}, 4 \mathrm{~mL}$ of the sample was prepared, containing $0.031 \mathrm{mmol}$ of GO, $0.030 \mathrm{mmol}$ of $0.1 \mathrm{M}$ nitric acid (V) and $0.0035 \mathrm{mmol}$ of magnesium nitrate. The heteroligand system differed by the presence of only $0.028 \mathrm{mmol} \mathrm{MCCh}$, so the molar ratio GO-MCCh was near 1:1. In turn, both the molar ratio of the ligand to the metal was about $8: 1$, which was intended to prevent early hydrolysis of the metal ion. All the experiments were carried out at $25.0 \pm 0.1{ }^{\circ} \mathrm{C}$ and ionic strength $0.1 \mathrm{~mol} \mathrm{~L}^{-1}\left(\mathrm{KNO}_{3}\right)$. The cell was standardized with two buffers: $\mathrm{pH}=3.926$ and $\mathrm{pH}=9.10$ [23]. Before each titration, the electrode system was calibrated in the $-\log \left[\mathrm{H}^{+}\right]$scale by strong acid-strong base titrations, $0.005 \mathrm{~mol} \mathrm{~L}^{-1} \mathrm{HNO}_{3}$ was neutralized by $0.1 \mathrm{~mol} \mathrm{~L}^{-1} \mathrm{NaOH}$ at temperature $25.0 \pm 0.1{ }^{\circ} \mathrm{C}$. The new parameters, differing from those obtained from the twopoint cell standardization on $\mathrm{pH}$, were then processed with Hyperquad2008 software to evaluate the overall, concentration formation constant: $\beta_{\mathrm{mll}}=\left[\mathrm{M} m \mathrm{~L} / \mathrm{L}^{\prime} l^{\prime} \mathrm{H} h\right] /$ $[\mathrm{M}]^{\mathrm{m}}[\mathrm{L}]^{\mathrm{l}}\left[\mathrm{L}^{\prime}\right]^{\mathrm{l}}[\mathrm{H}]^{\mathrm{h}}$. Goodness-of-fit was tested by two parameters: $\sigma$ (connected with the objective function) and $x^{2}$ statistics (test of randomness).

\section{FT-IR spectrophotometric measurements}

Polymer films, with and without magnesium ions, were prepared for use in the FT-IR studies. The optimum L:M ratio was accepted as being the same as in the potentiometric measurements. Initially a portion of $0.030 \mathrm{mmol}$ 
of nitric (V) acid was added to $0.028 \mathrm{mmol}$ of $\mathrm{MCCh}$ to dissolve the ligand $\mathrm{L}$. In other samples, after dissolving the ligand, $0.0035 \mathrm{mmol}$ magnesium ions were also added. Further samples differed from the previous ones by addition of $0.031 \mathrm{mmol}$ GO. By using $0.1 \mathrm{M} \mathrm{NaOH}$, each sample was brought to a definite $\mathrm{pH}$ within the range 2.4-6.5. The aqueous slurry formed was put on a Teflon plate and left to dry at room temperature. The FT-IR spectra of the $\mathrm{Mg}^{2+}$ ion and GO were recorded using a Thermo Scientific Nicolet IS50 spectrophotometer, with all of the polymer film being used in the FT-IR measurements. A total of 64 scans were obtained. The spectral resolution was $\pm 2 \mathrm{~cm}^{-1}$.

\section{Abbreviations}

DD: degree of deacetylation; FTIR: Fourier-transform infrared spectroscopy; L=MCCh: microcrystalline chitosan as ligand; GO: graphene oxide as ligand L'magnesium ion as metal-M; L:M: the ligand-to-metal concentration ratio; $\beta_{m / l / h}:\left[M_{m} L_{l} L_{l} H_{h}\right] /[M]^{m}[L]^{\prime}\left[L^{\prime}\right]^{\prime}[H]^{h}$ cumulative stability constant; $m, I, l$ l', h: number of metals (central ions), ligands and protons, respectively; concentrations in square brackets are equilibrium concentrations.

\section{Authors' contributions}

MEL proposed the research idea, carried out the potentiometric and FT-IR spectroscopic analysis, interpreted the spectral data and revised the manuscript. MW interpreted potentiometric data. AK interpreted the quantitative results and coordinated the final formulation. All authors read and approved the final manuscript.

\section{Acknowledgements}

This work was supported by the Medical University of Lodz (Statute Fund No. 503/3-014-02/503-31-001)

\section{Competing interests}

The authors declared that they have no competing interests.

\section{Availability of data and materials}

The datasets used and/or analysed during the current study are available from the corresponding author on reasonable request.

\section{Funding}

This work was supported by the Medical University of Lodz [Statute Fund No. 503/3-014-02/503-31-001].

\section{Publisher's Note}

Springer Nature remains neutral with regard to jurisdictional claims in published maps and institutional affiliations.

Received: 6 August 2018 Accepted: 11 April 2019

Published online: 19 April 2019

\section{References}

1. Dreyer DR, Park S, Bielawski WCh, Ruoff SR (2010) The chemistry of graphene oxide. Chem Soc Rev 39:228-240. https://doi.org/10.1039/b9171 $03 \mathrm{~g}$

2. Biomedical Applications of Graphene, He S, Liming Z, Min L, Zhijun Z (2012) Theranostics. 2(3):283-294. https://doi.org/10.7150/thno.3642
3. Zuo P-P, Feng H-F, Zhi-Zhen X, Zhang L-F, Zhang Y-L, Xia W, Zhang W-Q (2013) Fabrication of biocompatible and mechanically reinforced graphene oxide-chitosan nanocomposite films. Chem Cent J 7:39. https:// doi.org/10.1186/1752-153X-7-39

4. Li Ran, Tan Yanhong, Chen Xiuhua, Ren Fanggang, Zhang Yaofang, Zhifang Xu, Wang Hongwei (2013) Detection of promyelocytic leukemia/ retinoic acid receptor a (PML/RARa) fusion gene with functionalized graphene oxide. Int J Mol Sci 14:12863-12872. https://doi.org/10.3390/ ijms140612863

5. Subrahmanyam KS, Vivekchand RC, Govindaraj A, Rao CNR (2008) A study of graphenes prepared by different methods: characterization, properties and solubilization. J Mater Chem 18:1517-1523

6. Szabo T, Berkesi O, Forgo P, Josepovits K, Sanakis Y, Petridis D, Dekany I (2006) Evolution of surface functional groups in a series of progressively oxidized graphite oxides. Mater Chem 18:2740-2749

7. Yongzheng P, Nanda GS, Lin L (2012) The application of graphene oxide in drug delivery. Exp Opin Drug Del. 9:11

8. Kyzas GZ, Deliyanni EA, Matis KA (2014) Graphene oxide and its application as an adsorbent for wastewater treatment. J Chem Technol Biotechnol 89:196-205

9. Chun KC, Pumera M (2014) Chemical reduction of graphene oxide: a synthetic chemistry viewpoint. Chem Soc Rev. 43:291

10. Bojko $Ł$, Rynkiewicz AM (2015) Use of graphene in medicine - the study of literature. Problemy Nauk Stosowanych. 3:147-156

11. Bodek KH, Nowak KM, Kozakiewicz M, Bodek A, Michalska M (2015) Evolution of microcrystalline chitosan and fibrin membranes as plateletderived growth factor-BB carriers with amoxicillin. Inter J Pol Sci. 2015:13

12. Jung A (2014) Nanoparticles in medical applications- a direction of future? Pediatr Med Rodz 10(2):104-110. https://doi.org/10.15557/ PiMR.2014.0015

13. Kufelnicki A, Lichawska M, Bodek KH (2009) Interaction of microcrystalline chitosan (MCCh) with Mo (VI) in aqueous solution. J Appl Polym Sci 114:1619-1625

14. Schatz C, Viton C, Delair T, Pichot C, Domard A (2003) Typical physicochemical behaviors of chitosan in aqueous solution. Biomacromol 4:641-648

15. Pettit LD, Powell KJ. IUPAC stability constans datebase S.C., Datebase for Windows, Release 3. 1997

16. Lichawska ME, Kufelnicki A, Bodek KH (2010) Coordinative interactions of microcristalline chitosan (MCCh) with $\mathrm{Ca}$ (II) and Mg (II) in aqueous solutions. Clin Exp Med Lett. 51(1):69-73

17. Yau Y, Xiangdong C, Jinfeg Z, Baoging Z, Zuguan W, Xiaoyu L (2012) The effect of ambient humidyty on the electrical properties of graphene oxide films. Nanosc Res Lett. 7:363

18. Brugnerotto J, Lizardi J, Goycoolea FM, ArguĖelles-Monal W, Desbrie Áres J, Rinaudo M (2001) An infrared investigation in relation with chitin and chitosan characterization. Polymer 42:3569-3580

19. Taboada E, Cabrera G, Cardenas G (2003) Retention capacity of chitosan for copper and mercury ions. J Chil Chem Soc. 48:1

20. Pędras M (2009) Właściwości kompleksotwórcze wybranych ligandów organicznych względem jonów manganu (II). Praca Doktorska, Katowice

21. Tan SC, Khor E, Tan TK, Wong SM (1998) The degree of deacetylation of chitosan: advocating the first derivative UV-spectrophotometry method of determination. Talanta. 45(4):713-719

22. Irving HM, Miles MG, Pettit LD (1967) A study of some problems in determining the stoicheiometric proton dissociation constants of complexes by potentiometric titrations using a glass electrode. Anal Chim Acta 38:475-488

23. Buck RP, Rondinini S, Covington AK, Baucke FGK, Brett CMA, Camões MF Milton MJT, Mussini T, Naumann R, Pratt KW, Spitzer P, Wilson GS (2002) Measurement of $\mathrm{pH}$. Definition, standards, and procedures. Pure Appl Chem. 74:2169-2200 